\title{
Isolation and Characterization of Plant Growth Promoting Endophytic Diazotrophic Bacteria from Wheat Genotypes and their Influence on Plant Growth Promotion
}

\author{
Devendra Singh ${ }^{1}$, Neelam Geat ${ }^{3}$, Mahendra Vikram Singh Rajawat ${ }^{2}$, \\ Radha Prasanna ${ }^{1}$, Anil Kumar Saxena ${ }^{2}$ and Rajeev Kaushik ${ }^{1 *}$ \\ ${ }^{1}$ Division of Microbiology, ICAR-Indian Agricultural Research Institute, \\ New Delhi - 110012, India \\ ${ }^{2}$ ICAR-National Bureau of Agriculturally Important Microorganisms, Kushmaur, \\ Mau Nath Bhanjan, Uttar Pradesh - 275103, India \\ ${ }^{3}$ Division of Plant pathology, ICAR-Indian Agricultural Research Institute, \\ New Delhi - 110012, India \\ *Corresponding author
}

\author{
A B S T R A C T
}

\begin{tabular}{|l|}
\hline K e y w o r d s \\
Endophytic \\
bacteria, \\
Nitrogenase \\
enzyme, HCN, \\
Phosphate \\
solubilization, \\
Azospirillium sp. \\
\hline Article Info \\
\hline $\begin{array}{l}\text { Accepted: } \\
\text { 15 March } 2017 \\
\text { Available Online: } \\
\text { 10 April } 2017\end{array}$ \\
\hline
\end{tabular}

Nitrogen $(\mathrm{N})$ is an essential element for the growth and yield of wheat. Some endophytic bacteria can fix $\mathrm{N}_{2}$ from the air and convert to nitrogen compounds that can be utilized by plants. In this study, endophytic bacteria were isolated from one-month-old seedlings of 13 wheat genotypes growing without nitrogen fertilizer in the ICAR -IARI field. A total of 23 diazotrophic endophytes were isolated from 13 wheat genotypes used. Nitrogenase enzyme activities of endophytes were measured by acetylene reduction assay (ARA). Among 23 isolates, 17 isolates showed the IAA production, three isolates exhibited siderophore production ability and 13 isolates showed ammonia production ability. Thirteen isolates give clear halo zone around the colony on tricalcium phosphate containing Pikovaskaya's agar plates. None of them exhibited $\mathrm{HCN}$ production ability.Nitrogenase activity of isolates was ranged from 5 to $30 \mathrm{nmol} \mathrm{C}_{2} \mathrm{H}_{4} / \mathrm{mg}$ protein/h. Endophytes inoculation significantly increase the root length, root fresh weight and root dry weight. Likewise, endophytes inoculation also showed significant results on fresh weight and dry weight of shoot. Both the endophytes were identified as Azospirillium sp. by 16S rRNA gene sequencing.

\section{Introduction}

During the period of green revolution, high yielding varieties of crops have been developed to accomplish food demand for increasing population of India. Synthetic fertilizer and pesticides has applied for increasing production of crops and reduction of production loss because of disease development which create environmental and soil health problems. Cultivation of high- yielding varieties of crops, intensive cropping system, and imbalance use of chemical fertilizers is the main factors which develops nutrient imbalance in soil, low productivity, decrease soil fertility and low quality of food. Thus, it is becoming a serious problem to develop sustainable approaches for alleviation of detrimental influence of intensive practices used by farmers (Elkoca et al., 2010). Plant growth promoting endophytes mediates 
increased growth and yield of crops through direct or indirect mechanism. The direct mechanism of growth promotion of crops includes nitrogen fixation, phosphorus solubilization, production of phyto-hormones (e.g. auxins, gibberellins and cytokinins), siderophore production for iron sequestering and low production of ethylene (Idris et al., 2007; Verma et al., 2013). Application of microorganisms as inoculants enhances the availability of nutrients in soil and decreases the requirement of chemical fertilizers (Cakmakci et al., 2007a). Nitrogen fixing plant growth promoting rhizobacteria/ endophytic bacteria plays important role in addition of nitrogen in soil. Available various reports in literature confirmed that diazotrophic endophytes have been isolated from root, stem and leaves of several plants. Vigorous research in this area started after the isolation of the endophytic diazotrophic bacterium Gluconacetobacter diazotrophicus from a Brazilian variety of sugarcane (James and Olivares, 1998). Diazotrophic endophytes also trigger the plant growth and soil fertility via production of phytohormones, phosphate (P) solubilization, siderophore production and inhibition of or resistance to, certain pathogens (Hallman et al., 1997; Bottini et al., 2004; Conn and Franco, 2004; Chung et al., 2005; Son et al., 2005). Keeping in view this notion, we attempted the isolation and characterization of diazotrophic bacterial endophytes from wheat genotypes and their influence on plant growth.

\section{Materials and Methods}

\section{Wheat genotypes}

Seeds of 13 different wheat genotypes, namely CIM 412, WSM 24, 4HPYT 433, 4HPYT404, HD 2967, DPW 621-50, HPW B1, T-297/4HPYT 415, 4HPYT 414, GW-07112, HD 3086, and T-311/4HPYT 429 were collected from Division of Genetics, ICARIndian Agricultural Research Institute, New Delhi.

\section{Cultivation of different wheat genotype}

Different genotypes of wheat were cultivated without nitrogen fertilizers amendment at field of ICAR-IARI, New Delhi for 30 days. Three replicates were maintained for each genotypes.

Isolation of diazotrophic bacterial endophytes and enrichment in nitrogen fixing bacterium medium

After 30 days of sowing, shoots and roots samples were collected from different wheat genotypes for endophytes isolation. Nitrogen free semi solid media was used for isolation of diazotrophic bacterial endophytes. The fresh plant samples ( $1 \mathrm{~g}$ of shoot or root) were surface sterilized sequentially using $0.1 \%$ $\mathrm{HgCl}_{2}$ for 2 minutes and $70 \%$ alcohol for 60 seconds; washed with ten changes of sterile distilled water and crushed using mortar pestle under aseptic condition. The suspension was inoculated in nitrogen free semi solid medium for enrichment of nitrogen fixing microorganisms. After 3 subsequent culturing of the microorganisms from pellicle region after serial dilutions, were streaked on nutrient agar medium. The plates were incubated at $30^{\circ} \mathrm{C}$ for $24-48$ hrs and the colony growth was observed.

Plant growth promoting activities of endophytes

\section{IAA production}

IAA production was determined by inoculation of endophytic bacteria in tryptophan $(5 \mu \mathrm{g} / \mathrm{ml})$ containing nutrient broth and incubated at $28 \pm 2^{\circ} \mathrm{C}$ for 3 days. After incubation period, cultures were centrifuged at $5000 \mathrm{rpm}$ for 10 minute. $10 \mathrm{ml}$ of supernatant was mixed with two drops of orthophosphoric acid and $5 \mathrm{ml}$ Salkowski's reagent $(50 \mathrm{ml}, 35 \%$ perchloric acid; $1 \mathrm{ml} 0.5$ $\mathrm{FeCl}_{3}$ ). Pink to red colour development 
indicated of IAA production ability; the optical density (OD) was recorded at $530 \mathrm{~nm}$ using a spectrophotometer. The amount of IAA estimated by standard IAA graph and expressed as $\mu \mathrm{g} / \mathrm{mL}$ (Patten and Glick, 1996).

\section{Phosphorus solubilization}

Phosphate solubilization ability of endophytes was determined by spotting on tricalcium phosphate containing Pikovskaya (1948) agar plates. The plates were incubated at $28 \pm 2{ }^{\circ} \mathrm{C}$ for 5-7 days. Appearance of a clear zone around endophytes colonies indicated the Psolubilization ability.

\section{HCN production}

$\mathrm{HCN}$ production ability of endophytes was determined using Castric's method (Castric, 1975). All endophytic bacteria used, were grown in $10 \%$ tryptone soy agar supplemented with glycine $\left(4.4 \mathrm{gl}^{-1}\right)$. A Whatman filter paper No. 1 soaked in $2 \%$ sodium carbonate and $0.5 \%$ picric acid solution was placed to the underside of the Petri dish lids and the plates were sealed with parafilm and incubated at $30^{\circ} \mathrm{C}$ for 5-7 days. Change in colour of filter paper from yellow to red-brown indicated $\mathrm{HCN}$ production ability of endophytes.

\section{Ammonia production}

Detection of ammonia production was done by adding $1 \mathrm{ml}$ of Nessler's reagent to $72 \mathrm{~h}$ old cultures grown in peptone broth and positive samples exhibited yellowish brown colour (Dye, 1962).

\section{Siderophore production}

Ability to produce siderophore was analysed by spot inoculation of each isolate on nutrient agar medium supplemented with chrome azurol S (CAS) dye solution (Milagres et al., 1999). Plates were incubated at $30^{\circ} \mathrm{C}$ for 5 days for halo zone formation and the presence of orange halo zone around the colonies was taken as a positive test.

\section{ACC deaminase assay}

The ACC deaminase activity of the strains was assayed according to the method of Glick et al., (1995).

\section{Nitrogenase activity}

Acetylene reduction assay (ARA) was used for examination of nitrogenase activity of endophytes. Each endophyte culture was inoculated in $20 \mathrm{ml}$ capped tube containing 10 $\mathrm{ml}$ of nitrogen free semi solid agar media. The $10 \%$ volume of capped tube was replaced with $10 \%$ acetylene (v/v) and incubated at $30^{\circ} \mathrm{C}$ for 24 hours. Ethylene formation was measured by gas chromatography. The nitrogenase activity was calculated in unit nmol $\mathrm{C}_{2} \mathrm{H}_{4} / \mathrm{mg}$ protein/h (Lee and Yoshida, 1997).

\section{Hydroponic experiment}

For determination of influence of two selected diazotrophic endophytes DS-5 and DS-10 on plant growth a hydroponic experiment was carried out in phytotron at ICAR-Indian agricultural research institute, New Delhi. The wheat seeds were sterilized using $0.1 \% \mathrm{HgCl}_{2}$ and $70 \%$ alcohol. The broth cultures of both the endophytes were raised separately such that the inoculum contained $10^{9} \mathrm{cfu} \mathrm{mL}^{-1}$.

The sterilized seeds were coated with inoculum by soaking the seeds in broth for 30 minute. Seeds coated only with nutrient broth were used for control treatment. Seeds were germinated on wet cotton and $0.3 \%$ agar. After 4 days, the seedlings were transferred into the Hogland solution (1X) containing hydroponic system. Three replications were maintained for each of the three treatments. 


\section{Analysis of plant growth and biomass}

For observation of root length, shoot length, fresh weight and dry weight of root and shoot plants were harvested from hydroponic system and washed thoroughly with tap water followed by washing with $0.1 \% \mathrm{HCl}$ and then distilled water and then determined the root length, shoot length and fresh weight of root and shoot.

For determination of dry matter, root and shoot were air dried, after air drying, root and shoot sample were kept in paper bags, dried at $60^{\circ} \mathrm{C}$ to a constant weight and weighed.

\section{Identification of efficient endophytes}

Genomic DNA was extracted by using ZR fungal/bacterial DNA Mini Prep ${ }^{T M}$ genomic DNA isolation kit (ZYMO Research Corporation, USA) and amplified 16S rRNA gene of selected efficient endophytes using $\mathrm{PA}$ and $\mathrm{PH}$ universal primer. Amplified products of $16 \mathrm{~S}$ rRNA gene were purified using Qiagen purification Kit.

Sequencing of the purified 16S rRNA gene was done by Sci-Genome Pvt. Ltd., Bangalore. Obtained forward and reverse sequence of $16 \mathrm{~S}$ rRNA gene was aligned by CAP3 assembly. Aligned sequences were analyzed for maximum homogeneity with available 16S rRNA gene sequence in NCBI database through Blast tools and used the similarity index for their identification.

\section{Statistical analysis}

Data was analysed through one way ANOVA and grouping/ranking among various parameters were done by Tukey's method. Significance among parameters was analysed through two way ANOVA at 0.05 levels.

\section{Results and Discussion}

\section{Isolation, abundance and distribution of endophytes}

A total of 23 diazotrophic endophytes were isolated from 13 wheat genotypes. 4HPYT404 and K-65 showed maximum abundance of diazotrophic endophytes followed by GW07-112, HD-3086 and T-311/4HPYT-429. Diazotrophic endophytes distribution was found more in roots in comparison to shoot (Fig. 1).

Characterization of plant $\begin{array}{r}\text { growth } \\ \text { promoting activities } \\ \text { diazotrophic endophytes }\end{array}$
isolated

Among 23 isolates, a total seventeen isolates, three isolates and thirteen isolates exhibited IAA production, siderophore production and phosphate solubilization ability respectively. None of them exhibited $\mathrm{HCN}$ production ability. Thirteen isolates also showed ammonia production ability. Nitrogenase activity of isolates was ranged from 5 to 30 nmol C2H4/mg protein/h (Table 1 and Fig. 2). On the basis of these PGP activities DS-5 and DS-10 were selected for further study.

\section{Influence of endophytes on plant growth}

Endophytes inoculation significantly increased the root length, root fresh weight and root dry weight. Likewise, endophytes inoculation also showed significant results on fresh weight and dry weight. Endophytes inoculations were showed no significant result irrespective to shoot length of wheat seedling. There was no significance difference among the treatments. Diazotrophic endophytes inoculation increased the root length, root fresh weight and root dry weight by $61 \%$, $107 \%$ and $100 \%$ over the control, respectively. 
Table.1 Characterization of PGPR activities of diazotrophic endophytes isolated from wheat genotypes

\begin{tabular}{|c|c|c|c|c|c|c|c|}
\hline Isolates & $\begin{array}{l}\text { IAA } \\
(\mu \mathrm{g} / \mathrm{mL})\end{array}$ & Siderophore & $\begin{array}{l}\text { Phosphate } \\
\text { solubilization }\end{array}$ & $\mathrm{HCN}$ & Ammonia & $\begin{array}{c}\text { Nitrogenase } \\
\text { activity } \\
\text { (nmol } \mathrm{C}_{2} \mathrm{H}_{4} / \mathrm{mg} \\
\text { protein } / \mathrm{h})\end{array}$ & $\begin{array}{l}\text { ACC } \\
\text { deaminase } \\
\text { activity }\end{array}$ \\
\hline DS-1 & 5 & - & - & - & + & 12 & - \\
\hline DS-2 & 7 & - & - & - & + & 11 & - \\
\hline DS-3 & - & - & - & - & + & 21 & - \\
\hline DS-4 & 5 & - & - & - & + & 23 & - \\
\hline DS-5 & 19 & + & +++ & - & +++ & 24 & - \\
\hline DS-6 & - & - & - & - & + & 21 & - \\
\hline DS-7 & 3 & - & - & - & - & 12 & - \\
\hline DS-8 & 11 & - & - & - & - & 11 & - \\
\hline DS-9 & 14 & - & - & & + & 5 & - \\
\hline DS-10 & 23 & + & ++++ & - & +++ & 30 & - \\
\hline DS-11 & 12.4 & - & - & - & - & 21 & - \\
\hline DS-12 & 11.5 & - & - & - & - & 31 & - \\
\hline DS-13 & 10 & - & - & - & - & 15 & - \\
\hline DS-14 & - & - & - & - & - & 14 & - \\
\hline DS-15 & 7 & - & - & - & - & 13 & - \\
\hline DS-16 & 6 & - & - & - & - & 12 & - \\
\hline DS-17 & 12 & - & - & - & - & 13 & - \\
\hline DS-18 & - & - & + & - & - & 14 & - \\
\hline DS-19 & 11.56 & + & + & - & + & 16 & - \\
\hline DS-22 & 8.5 & - & + & - & + & 23 & - \\
\hline DS-21 & - & - & - & - & ++ & 27 & - \\
\hline DS-22 & 6.5 & - & - & - & + & 28 & - \\
\hline DS-23 & - & - & - & - & + & 30 & - \\
\hline
\end{tabular}

Table.2 Influence of endophytic diazotrophic bacteria on plant growth

\begin{tabular}{|l|l|l|l|l|l|l|}
\hline Treatments & $\begin{array}{l}\text { Root length } \\
(\mathrm{cm})\end{array}$ & $\begin{array}{l}\text { Root fresh } \\
\text { weight }(\mathrm{g})\end{array}$ & $\begin{array}{l}\text { Root dry } \\
\text { weight }(\mathrm{g})\end{array}$ & $\begin{array}{l}\text { Shoot } \\
\text { length }(\mathrm{cm})\end{array}$ & $\begin{array}{l}\text { Shoot fresh } \\
\text { weight }(\mathrm{g})\end{array}$ & $\begin{array}{l}\text { Shoot dry } \\
\text { weight }(\mathrm{g})\end{array}$ \\
\hline Control & $13.33 \pm 1.53^{\mathrm{b}}$ & $0.46 \pm 0.04^{\mathrm{b}}$ & $0.17 \pm 0.02^{\mathrm{b}}$ & $20.33 \pm 2.52^{\mathrm{a}}$ & $1.50 \pm 0.10^{\mathrm{b}}$ & $0.54 \pm 0.05^{\mathrm{b}}$ \\
\hline DS-5 & $20.33 \pm 2.52^{\mathrm{ab}}$ & $0.91 \pm 0.09^{\mathrm{a}}$ & $0.32 \pm 0.04^{\mathrm{a}}$ & $25.003 .00^{\mathrm{a}}$ & $3.00 \pm 0.26^{\mathrm{a}}$ & $1.01 \pm 0.14^{\mathrm{a}}$ \\
\hline DS-10 & $22.33 \pm 2.16^{\mathrm{a}}$ & $1.00 \pm 0.10^{\mathrm{a}}$ & $0.34 \pm 0.06^{\mathrm{a}}$ & $24.67 \pm 2.08^{\mathrm{a}}$ & $2.59 \pm 0.40^{\mathrm{a}}$ & $0.97 \pm 0.09^{\mathrm{a}}$ \\
\hline
\end{tabular}


Fig.1 Abundance and distribution of different endophytic diazotrophic bacterial morphotypes isolated from various wheat genotypes using nitrogen free semi solid media
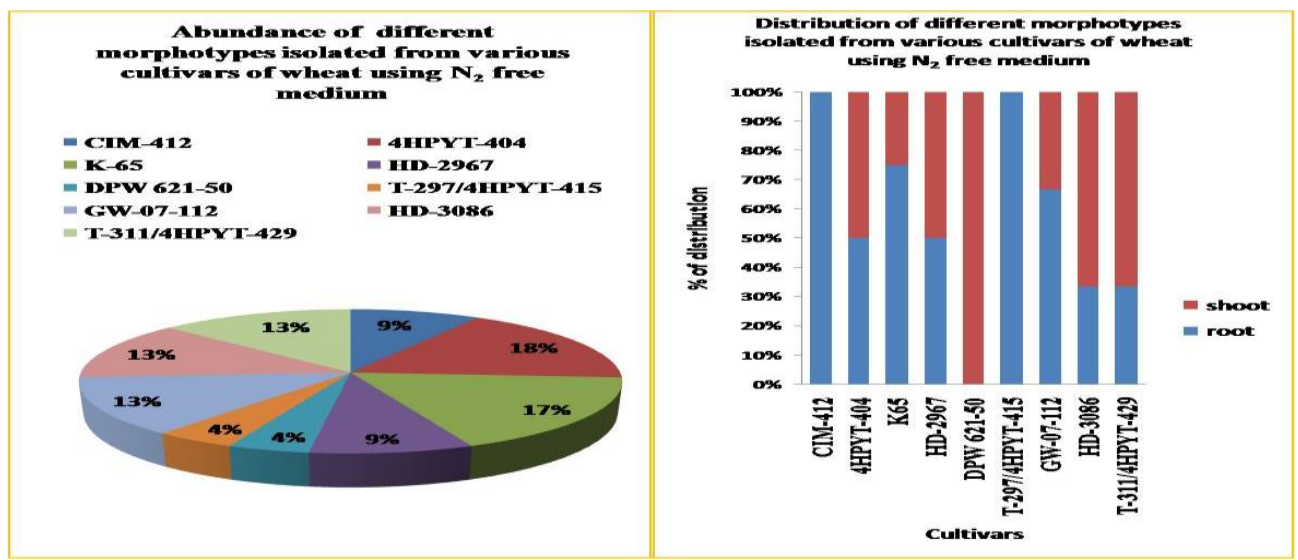

Fig.2 Screening of diazotrophic endophytes for plant growth promoting activities

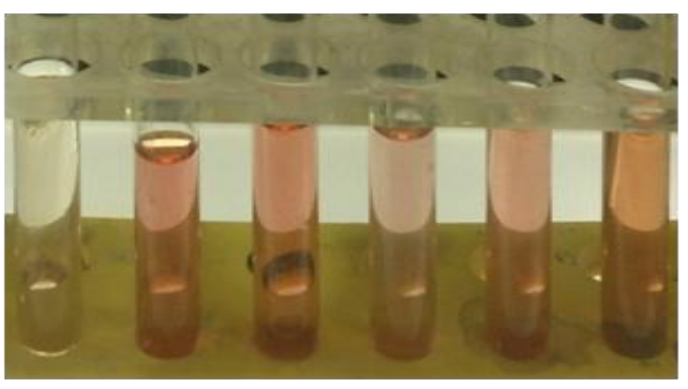

A. IAA

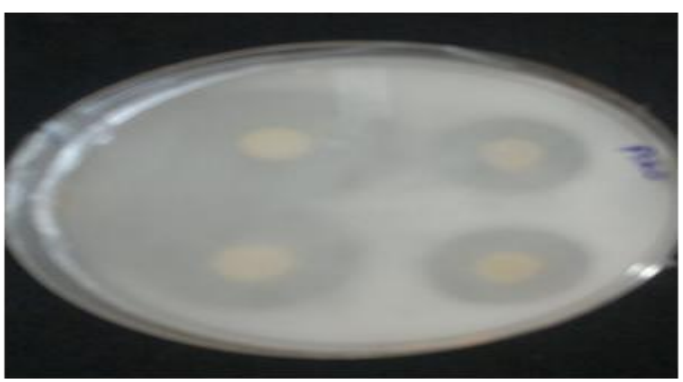

C. Phosphorus sohubilization

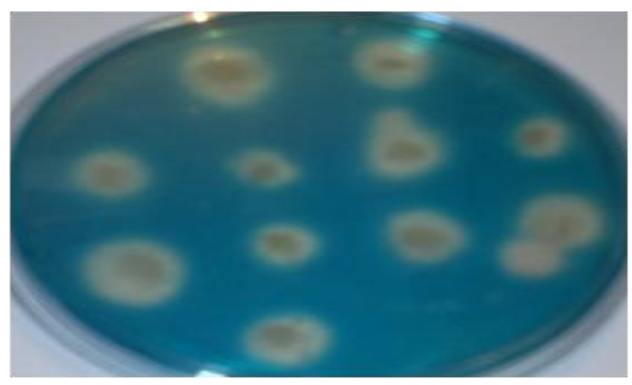

B. Siderophore

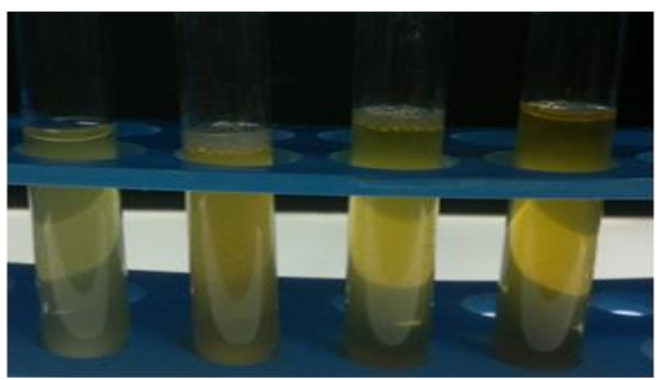

D. Ammonia

various plants (Hallman et al., 1997; James and Olivares, 1998; Muthukumarasamy et al., 2005). The occurrence of 23 morphotypes from the roots and shoots of 13 wheat genotypes is an interesting observation. However, occurrence of as many as 20 types of endophytic bacteria, comprising both nitrogen-fixing and non-nitrogen- fixing from roots and shoots of rice plants has been reported (Ladha and Reddy, 2000). Existence of higher proportion of diazotrophic 
endophytes in roots compared with shoots supports the presumption that roots may be a prime niche for growth and nitrogen fixation by endophytes (James and Olivares, 1998; Ladha and Reddy, 2000). Although there were distinct differences in their pellicle formation, nitrogenase activity, IAA production, $\mathrm{P}$ solubilization activity, siderophore production and ammonia production. Sub pellicle formation in nitrogen free semisolid media by diazotrophic endophytes agrees with the reports on several Azosprillum species (Dobereiner, 1995). Sub pellicle formation by endophytes indicates that isolates fix nitrogen preferably under semi-anaerobic condition. Acetylene reduction assay confirmed the diazotrophic nature of all 23 isolates. Our results showed that inoculation of diazotrophic endophytes significantly increase the root length, root fresh weight, root dry weight, shoot fresh weight and shoot dry weight. Similar observations have been made in other diazotrophic endophytes, such as Gluconacetobacter diazotrophicus in sugarcane (James and Olivares, 1998), Azoarcus spp. in rice and kallar grass (Reinhold-Hurek and Hurek, 1998), Herbaspirillum spp. in sugarcane and rice (James and Olivares, 1998) and Serratia marcescens in rice (Gyaneshwar et al., 2001). Plant growth-promoting effect of DS-5 and DS-10 could be because of nitrogen fixation alone or the combined effects of IAA and $\mathrm{P}$ solubilization activity. Further work based on field trials is needed to test the usefulness of these isolates. In conclusion, results of the present study show that wheat genotypes do harbour plant growth-promoting endophytic bacteria.

\section{References}

Bottini, R., Cassan, F., Piccoli, P. 2004. Gibberellin production by bacteria and its involvement in plant growth promotion and yield increase. Appl. Microbiol.
Biotechnol., 65: 497-503.

Cakmakci, R., Donmez, M.F., Erdogan, U. 2007a. The effect of plant growth promoting rhizobacteria on barley seedling growth, nutrient uptake, some soil properties, and bacterial counts. Turk. J. Agric. For., 31: 189-199.

Castric, P.A. 1975. Hydrogen cyanide, a secondary metabolite of Pseudomonas aeruginosa. Can. J. Microbiol., 21: 613618.

Chung, H., Park, M., Madhaiyan, M., Seshadri, S., Song, J., Cho, H., Sa, T. 2005. Isolation and characterization of phosphate solubilizing bacteria from the rhizosphere of crop plants of Korea. Soil Biol. Biochem., 37: 1970-1974.

Conn, V.M., Franco, C.M.M. 2004. Analysis of the endophytic actinobacterial population in the roots of wheat (Triticum aestivum L.) by terminal restriction fragment length polymorphism and sequencing of $16 \mathrm{~S}$ rRNA clones. Appl. Environ. Microbiol., 70: $1787-1794$.

Dobereiner, J. 1995. Isolation and identification of aerobic nitrogen-fixing bacteria from soil and plants. In Methods in Applied Soil Microbiology and Biochemistry ed. Alef, K. and Nannipieri, P. pp. 134-141. London: Academic Press.

Dye, D.W. 1962. The inadequacy of the usual determinative tests for identification of Xanthomonas sp. New Zealand J. Sci., 5: 393-416.

Elkoca, E., Turan, M., Donmez, M.F. 2010. Effects of single, dual and triple inoculation with Bacillus subtilis, Bacillus megaterium and Rhizobium leguminosarum bv. phaseoil on nodulation, nutrient uptake, yield and yield parameters of common bean (Phaseolus vulgaris L. cv. 'Elkoca-05'). J. Plant Nutr., 33: 2104-2119.

Glick, B.R., Karaturovíc, D., Newell, P. 1995. A novel procedure for rapid isolation of plant growth-promoting rhizobacteria. Can. J. Microbiol., 41: 533-6.

Gyaneshwar, P., James, E.K., Mathan, N., Reddy, P.M., Reinhold- Hurek, B., 
Ladha, J.K. 2001. Endophytic colonization of rice by a diazotrophic strain of Serratia marcescens. $J$. Bacteriol., 183: 2634-2645.

Hallman, J., Quadt-Hallman, A., Mahaffee, W.F., Kloepper, J.W. 1997. Bacterial endophytes in agricultural crops. Can. J. Microbiol., 43: 895-914.

Idris, E.E., Iglesias, D.J., Talon, M., Borriss, R. 2007. Tryptophan dependent production of indole-3-acetic acid (IAA) affects level of plant growth promotion by Bacillus amyloliquefaciens FZB42. Mol. PlantMicrobe Interact., 20: 619-626.

James, E.K., Olivares, F.L. 1998. Infection and colonization of sugarcane and other gramineous plants by endophytic diazotrophs. Crit. Rev. Plant Sci., 17: 77119.

Ladha, J.K., Reddy, P.M. 2000. Step towards nitrogen fixation in Rice. In the Quest for Nitrogen Fixation in Rice ed. Ladha, J.K. and Reddy, P.M. pp. 33-46. Manila, Philippines: International Rice Research Institute.

Lee, K.K., Yoshida, T. 1997. An assay technique of measurement of nitrogenase activity in root zone of rice for varietal screening by the acetylene reduction method. P. Soil, 46: 127-134.

Milagres, A.M.F., Machuca, A., Napoleão, D. 1999. Detection of siderophore production from several fungi and bacteria by a modification of chrome azurol S (CAS) agar plate assay. $J$. Microbiol. M., 37(1): 1-6.
Muthukumarasamy, R., Cleenwerck, I., Revathi, G., Vadivelu, M., Janssens, D., Hoste, B., Gum, K.U., Park, K. 2005. Natural association of Gluconoacetobacter diazotrophicus and diazotrophic Acetobacter peroxydans with wetland rice. Syst. Appl. Microbiol., 28: 277-286.

Patten, C., Glick, B. 2002. Role of Pseudomonas putida indole acetic acid in development of the host plant root system. Appl. Environ. Microbiol., 37953801.

Pikovskaya, R.I. 1948. Mobilization of phosphorous in soil in connection with vital activity of some microbial species. Mikrobiologiya, 17: 362-370.

Reinhold-Hurek, B., Hurek, T. 1998. Interactions of gramineous plants with Azoarcus spp. and other diazotrophs: identification, localization and perspectives to study their function. Crit. Rev. Plant Sci., 17: 29-54.

Son, H., Park, G., Cha, M., Heo, M. 2005. Solubilization of insoluble inorganic phosphates by a novel salt and $\mathrm{pH}$ tolerant Pantoea agglomerans R-42 isolated from soyabean rhizosphere. Biores. Technol., 97: 204-210.

Verma, J.P., Yadav, J., Tiwari, K.N., Kumar, A. 2013. Effect of indigenous Mesorhizobium spp. and plant growth promoting rhizobacteria on yields and nutrients uptake of chickpea (Cicer arietinum L.) under sustainable agriculture. Ecol. Eng., 51: 282-286.

\section{How to cite this article:}

Devendra Singh, Neelam Geat, Mahendra Vikram Singh Rajawat, Radha Prasanna, Anil Kumar Saxena and Rajeev Kaushik. 2017. Isolation and characterization of Plant growth promoting endophytic diazotrophic bacteria from wheat genotypes and their influence on plant growth promotion. Int.J.Curr.Microbiol.App.Sci. 6(4): 1533-1540.

doi: https://doi.org/10.20546/ijcmas.2017.604.188 